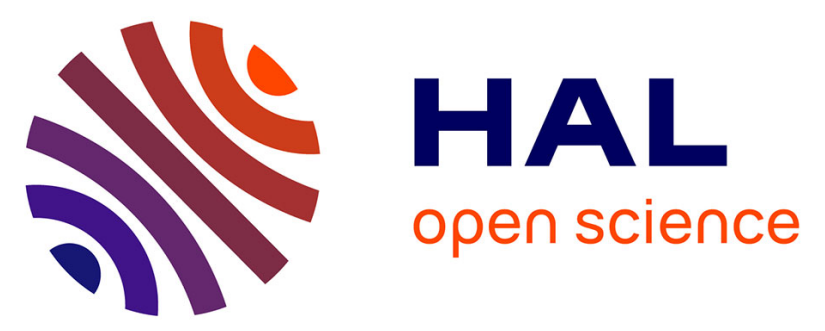

\title{
Highly Syndiotactic or Isotactic Polyhydroxyalkanoates by Ligand-Controlled Yttrium-Catalyzed Stereoselective Ring-Opening Polymerization of Functional Racemic $\beta$-Lactones
}

Romain Ligny, Mikko M. Hänninen, Sophie M. Guillaume, Jean-François

Carpentier

\section{To cite this version:}

Romain Ligny, Mikko M. Hänninen, Sophie M. Guillaume, Jean-François Carpentier. Highly Syndiotactic or Isotactic Polyhydroxyalkanoates by Ligand-Controlled Yttrium-Catalyzed Stereoselective Ring-Opening Polymerization of Functional Racemic $\beta$-Lactones. Angewandte Chemie International Edition, 2017, 56 (35), pp.10388-10393. 10.1002/anie.201704283 . hal-01579647

\section{HAL Id: hal-01579647}

\author{
https://hal-univ-rennes1.archives-ouvertes.fr/hal-01579647
}

Submitted on 31 Aug 2017

HAL is a multi-disciplinary open access archive for the deposit and dissemination of scientific research documents, whether they are published or not. The documents may come from teaching and research institutions in France or abroad, or from public or private research centers.
L'archive ouverte pluridisciplinaire HAL, est destinée au dépôt et à la diffusion de documents scientifiques de niveau recherche, publiés ou non, émanant des établissements d'enseignement et de recherche français ou étrangers, des laboratoires publics ou privés. 


\title{
Highly Syndiotactic to Isotactic Polyhydroxyalkanoates via Ligand- Controlled Yttrium-Catalyzed Stereoselective Ring-Opening Polymerization of Functional Racemic $\beta$-lactones**
}

\author{
Romain Ligny, ${ }^{a}$ Mikko M. Hänninen, ${ }^{b}$ Sophie M. Guillaume, ${ }^{a, *}$ and Jean-François Carpentier ${ }^{a, *}$
}

\begin{abstract}
Reported herein is the first stereoselective controlled ROP of a specific family of racemic functional $\beta$-lactones, namely 4-alko$x y$-methylene- $\beta$-propiolactones $\left(B P L^{O R}{ }_{S}\right)$, using yttrium catalysts stabilized by nonchiral tetradentate amino-alkoxy-bisphenolate ligands $\left\{O N O O^{R '}\right\}^{2-}$, combining both a good activity and a high degree of control over the molar masses of the resulting functional poly(3-hydroxyalkanoate)s $P H B^{O R}$. The simple modification of ortho,para- $R$ ' substituents on the ligand platform allows a complete reversal from virtually pure syndioselective $\left(P_{s}\right.$ up to 0.91 with $R^{\prime}=$ cumyl) to pure isoselective $\left(P_{i}\right.$ up to 0.93 with $\left.R^{\prime}=C l\right) R O P$, as supported by DFT insights. This is the first example of a highly isoselective ROP of a racemic chiral $\beta$-lactone.
\end{abstract}

$\boldsymbol{R}$ ing-opening polymerization (ROP) of cyclic esters is the method of choice for preparing polyesters with a bespoke architecture. Tremendous efforts have been spent in the past two decades for developing highly effective metal-based or organo-catalysts able to fine-tune the molar mass, terminal groups and the microstructure of the polymers. ${ }^{[1]}$ A specific point of major interest in this research field is the control of tacticity -and, as a result, of physicochemical properties- when starting from racemic mixtures of chiral cyclic monomers. Hence, much work has been devoted to the ROP of racemic lactide ( $r a c$-LA) for the synthesis of biosourced degradable polymer alternatives to regular petrochemical-based plastics. Heterotactic polylactide (PLA) is quite commonly obtained, most often as the result of a chain-end stereocontrolled (CEC) mechanism which minimizes steric interactions between the last inserted monomer unit in the growing polymer chain and the new incoming monomer unit, thus resulting in the alternation of monomer units with opposite $(R, R / S, S)$ configuration. On the other hand, the preparation of valuable crystalline (sometimes stereocomplexed) isotactic PLA from the ROP of rac-LA is much more challenging; only a few catalysts/initiators, essentially based on group $13\left(\mathrm{Al},{ }^{[2]}\right.$ $\left.\mathrm{In}^{[3]}\right), 12(\mathrm{Zn}),{ }^{[4]} 4(\mathrm{Zr})^{[5]}$ and 3 (rare-earth) ${ }^{[6]}$ metals, have proved able to do so with probabilities of isotactic enchainment $\left(P_{\mathrm{i}}\right)$ up to 0.97 .

[a] R. Ligny, Dr. S. M. Guillaume, Prof. Dr. J.-F. Carpentier Institut des Sciences Chimiques de Rennes, UMR 6226 CNRS Université de Rennes 1, F-35042 Rennes (France)

E-mail: sophie.guillaume@univ-rennes1.fr jean-francois.carpentier@univ-rennes1.fr

[b] Dr. M. M. Hänninen, Department of Chemistry University of Jyväskylä, Jyväskylä, P.O. Box 35, FI-40014, Finland

[**] This research was financially supported in part by the Region Bretagne (Ph.D. grant to R.L.) and by the Academy of Finland (M. M. H. grant number 274505).

Supporting information for this article is available on the WWW under http://dx.doi.org/10.1002/anie.201xxxxxx.
Extension of stereoselective ROP to other chiral cyclic esters is much less documented. In particular, $\beta$-lactones such as the prototypical $\beta$-butyrolactone (BL), are more reluctant to ring-open and few catalysts are able to perform their ROP, even less in a stereoselective fashion. ${ }^{[7]}$ We have shown that yttrium catalysts stabilized by nonchiral tetradentate amino-alkoxy-bisphenolate ligands $\left\{\mathrm{ONOO}^{\mathrm{R} \prime 2}\right\}^{2-}$ offer highly syndiotactic poly(3-hydroxybutyrate) (PHB) with a probability of syndio enchainment $\left(P_{\mathrm{s}}\right)$ up to 0.96 , provided sterically bulky aryl-containing substituents are installed on the ortho-site of phenolate ligands. ${ }^{[8]}$ This ROP catalysis has been extended to different racemic $\beta$-lactones, ${ }^{[9]}$ in particular to valuable functional ones such as alkyl $\beta$-malolactonates (i.e., 4alkoxycarbonyl- $\beta$-lactones, $\mathrm{MLA}^{\mathrm{R}} ; \mathrm{R}=$ allyl, benzyl); ${ }^{[10]}$ in this latter case, surprisingly, only yttrium catalysts bearing an ortho,para $(o, p)$-dichloro-substituted $\left\{\mathrm{ONOO}^{\mathrm{Cl}}\right\}^{2-}$ ligand enabled achieving highly syndiotactic polymerizations $\left(P_{\mathrm{s}}>0.95\right)$. Regular catalysts incorporating sterically crowded R' alkyl/aryl $o, p$ - substituents on the $\left\{\mathrm{ONOO}^{\mathrm{R}} 2\right\}^{2-}$ platform afforded only modest syndioselectivity. All these syndioselective reactions operated through a CEC mechanism, as revealed by NMR studies and also pinpointed by DFT computations. ${ }^{[11]}$ On the other hand, the best isoselectivity in the ROP of racemic $\mathrm{BL}$ was achieved by a $\mathrm{Cr}$ catalyst with a modest isotacticity bias $\left(P_{\mathrm{i}}\right.$ ca. 0.65$)$ and no control over molar masses. ${ }^{[12]}$

We herein report on the first stereoselective ROP of another class of racemic functional $\beta$-lactones, namely 4-alkoxymethylene$\beta$-propiolactones $\left(\mathrm{BPL}^{\mathrm{OR}} \mathrm{s}\right)$, combining both a good catalytic activity and a high degree of control over the molar masses of the resulting alkoxy-functional poly(3-hydroxyalkanoate)s $\mathrm{PHB}^{\mathrm{OR}} \mathrm{s}$. It is shown that simple modification of $o, p$ - $\mathrm{R}^{\prime}$ substituents on the $\left\{\mathrm{ONXO}^{\mathrm{R}^{\prime 2}}\right\}^{2-}$ platform of yttrium catalysts allows switching completely from syndioselective to isoselective polymerization of this specific class of $\beta$-lactones; quite unexpectedly and uniquely, catalysts bearing an $o, p$-dichloro-substituted ligand deliver highly isotactic polyesters $(P$ $>0.90$ ). This is the first example of a highly isoselective ROP of a racemic chiral $\beta$-lactone.

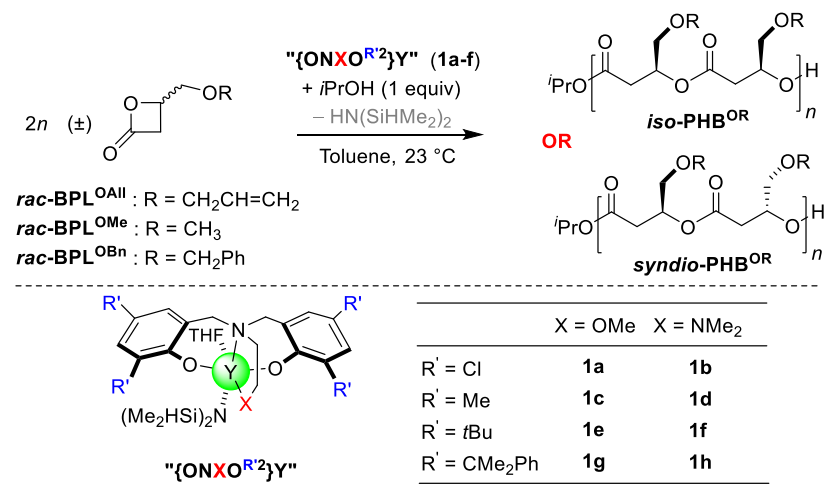

Scheme 1. Stereoselective synthesis of isotactic and syndiotactic $\mathrm{PHB}^{\mathrm{OR}} \mathrm{S}$ from the $\mathrm{ROP}$ of racemic $\mathrm{BPL}^{\mathrm{OR}_{\mathrm{S}} \text {. }}$ 
$\mathrm{ROP}$ reactions were performed on three racemic $\mathrm{BPL}^{\mathrm{O}}$ monomers $(\mathrm{R}=$ allyl, benzyl, methyl) (Scheme 1$)$, which were readily prepared by carbonylation of the corresponding racemic epoxides following Coates' Co-catalyzed protocol (Figure S1 in the Supporting Information). ${ }^{[13]}$ As for previous studies, ${ }^{[8,10]}$ yttriumisopropoxide catalysts/initiators were conveniently generated in situ from the action of 1 equiv. of $i \mathrm{PrOH}$ onto the respective amido precursors 1a-g that were selected with ligands differing by the nature of the $\mathrm{R}$ ' phenolate substituents.

Catalytic systems with ligands incorporating bulky alkyl $o, p$ substituents $(t \mathrm{Bu}, \mathbf{1 e}, \mathbf{1 f}$; cumyl, $\mathbf{1 g}, \mathbf{1 h})$ revealed quite active at $20{ }^{\circ} \mathrm{C}$ in toluene, allowing typically quantitative conversion of ca $50-100$ equiv. of $r a c-B P L^{\mathrm{OR}}$ within $2 \mathrm{~h}$ (Tables $1, \mathrm{~S} 1$ ). On the other hand, catalysts based on ligands having small $\mathrm{Cl}(\mathbf{1 a}, \mathbf{1 b})$ or $\mathrm{Me}(\mathbf{1 c}$ 1d) $o, p$-substituents proved somewhat more sluggish. This observation is peculiar and might appear counterintuitive at first sight, since the approach of the monomer is anticipated to be favored with lower steric hindrance around the metal center; also, the presence of electron-withdrawing substituents (such as $\mathrm{Cl}$ ) on ligands has been reported to often increase ROP reaction rates. ${ }^{[2 f]}$ We also noted that pre-catalyst systems with a $\mathrm{NMe}_{2}$ cap (X) on the ligand $(\mathbf{1 b}, \mathbf{1 d}, \mathbf{1 f}, \mathbf{1 h})$ are systematically more active than their OMe-capped counterpart (1a, 1c, 1e, 1g), respectively, regardless of the $o, p$-substituents (Tables 1, S1). Hence, the dichloro OMe-capped system (1a), poorly active at room temperature (Table S1), can be valuably substituted by the dichloro $\mathrm{NMe}_{2}$-capped system (1b) which offers high $\mathrm{BPL}^{\mathrm{OR}}$ conversion within reasonable times under the same operating conditions (Table 1, entry 2). Detailed monitoring of NMR-scale reactions performed on $\mathrm{rac}^{-\mathrm{BPL}^{\mathrm{OAll}}}$ at $23^{\circ} \mathrm{C}$ with the catalyst systems that are not too active, confirmed these kinetic trends derived from batch experiments, and linear semi-logarithmic plots established that the reactions are first-order in monomer $\left(k_{\text {app }}\left(\mathrm{min}^{-1}\right)=2.43 \pm 0.10, \mathbf{1 g} ; 2.38 \pm 0.10 \times 10^{-2}, \mathbf{1 b}\right.$; $\left.1.07 \pm 0.09 \times 10^{-2}, \mathbf{1 d} ; 0.62 \pm 0.03 \times 10^{-2}, \mathbf{1 c} ; 0.10 \pm 0.01 \times 10^{-2}, \mathbf{1 a}\right)$ (Table S2, Figure S2). Reactivity of the catalyst systems in THF was significantly lower, ${ }^{[14]}$ most likely as the result of competitive coordination of THF vs. monomer onto the metallic center; such a behavior has been previously observed in the ROP of alike polar cyclic ester monomers. ${ }^{[10,15]}$

The reactions proceeded with a fair control over the $\mathrm{PHB}^{\mathrm{OR}} \mathrm{S}$ molar masses. This is evidenced by (i) the quite good agreement between experimental molar mass values $\left(M_{\mathrm{n}, \mathrm{NMR}}\right)$ and theoretical ones $\left(M_{\mathrm{n}, \text { theo }}\right)$, as determined by ${ }^{1} \mathrm{H}$ NMR analyses (from the isopropoxycarbonyl end-group and main-chain resonances), and monomer-to-initiator along with $\mathrm{BPL}^{\mathrm{OR}}$ conversion, respectively, (ii) the linear growth of experimental molar masses (e.g., $M_{\mathrm{n}, \mathrm{NMR}}$ ) as a function of monomer conversion as illustrated with BPL ${ }^{\text {OAll }}$ (Figure S3), as well as (iii) the rather narrow dispersity values (1.07 $\left.\leq \bigoplus_{\mathrm{M}} \leq 1.23\right)$ as determined by SEC analysis. The analysis of the end-groups was conducted by ${ }^{1} \mathrm{H}$ and ${ }^{13} \mathrm{C}\left\{{ }^{1} \mathrm{H}\right\}$ NMR spectroscopy (Figures S4-S9) as well as by ESI mass spectrometry (Figures $\mathrm{S} 10-\mathrm{S} 17)$. The latter MS analyses of $\mathrm{PHB}^{\mathrm{OR}} \mathrm{S}(\mathrm{OR}=\mathrm{OAll}$, OMe $)$ showed a major set of peaks assignable to polyester chains with hydroxy and isoproxycarbonyl end-groups, with peaks separated by 142 and 116 amu, respectively.

The stereoselectivity of the ROP reactions was much affected by the nature of the $\mathrm{R}^{\prime} o, p$-substituents on the phenolate ligand. As a matter of fact, a complete reversal from virtually pure syndiotactic $\left(P_{\mathrm{s}}\right.$ up to 0.91$)$ to pure isotactic ( $P_{\mathrm{i}}$ up to 0.93 ) was observed upon switching from dicumyl- (1g) to dichloro- (1a) substituted ligands in the catalyst/initiator, respectively (Table 1 , entries 1,6). ${ }^{[16]}$ This striking change in stereoselectivity was best assessed by ${ }^{13} \mathrm{C}\left\{{ }^{1} \mathrm{H}\right\}$ NMR spectroscopy of the resulting $\mathrm{PHB}^{\mathrm{OR}_{\mathrm{S}}}$ (Figures S5, S7, S9). In line with previous observations on related poly(3-hydroxyalkonate)s, namely PHB, ${ }^{[8]}$ and allyl and benzyl $\beta$-malolactonates $\left(\mathrm{PMLA}^{\mathrm{R}} ; \mathrm{R}=\right.$ allyl, benzyl) ${ }^{[10]}$ we observed that the ${ }^{13} \mathrm{C}$ NMR signals of the main chain carbonyl and methine carbons as well as that of the methylene side-chains are diagnostic of the tacticity of $\mathrm{PHB}^{\mathrm{OR}}$; the case of PHB $^{\text {OAll }}$ is illustrated in Figure 1. Basically, these regions of the NMR spectra show signals at the diad level, enabling a facile determination of the $P_{\mathrm{s}} / P_{\mathrm{i}}$ values (i.e., $\left.P_{\mathrm{s}}=1-P_{\mathrm{i}}\right)^{[17]}$ To ascertain the assignments, pure isotactic polymers were independently prepared by ROP of enantiomerically pure $(S)$-BPL ${ }^{\text {OAll }}$ and $(R)$ $\mathrm{BPL}^{\mathrm{OMe}}$ (Table S1). The ${ }^{13} \mathrm{C}$ NMR spectra of these two isotactic materials each displayed a single sharp resonance for the three aforementioned types of carbons. The polymers prepared from racBPL $^{\text {OAll }}$ with $o, p$-dichloro-substituted catalysts/initiators $\mathbf{1 a}$ and $\mathbf{1 b}$ showed the same strong signals, along with a minor one either downfield $(\mathrm{C}=\mathrm{O}$ and $\mathrm{CH})$ or upfield $\left(\mathrm{CH}_{2}\right)$, assigned to the syndio diad. In contrast, the polymers prepared with the dicumylsubstituted catalysts/initiators $\mathbf{1 g}$ and $\mathbf{1 h}$, exhibited a complete switch in intensity between these two signals for each carbon, indicative of highly syndiotactic polymers. Similar observations were made for $\mathrm{PHB}^{\mathrm{OMe}}$ and $\mathrm{PHB}^{\mathrm{OBn}}$ (Figures S18, S19).

Table 1. ROP of rac-BPL ${ }^{\mathrm{OR}}$ mediated by $1 / \mathrm{PPrOH}$ systems in toluene (refer to Table $\mathrm{S} 1$ for further experiments).

\begin{tabular}{|c|c|c|c|c|c|c|c|c|c|c|c|}
\hline Entry & $\mathrm{BPL}^{\mathrm{OR}}$ & Catalyst & $\left.\left[\mathrm{BPL}^{\mathrm{OR}}\right]_{0:[1}\right]_{0:[}[\mathrm{PrOH}]_{0}[\mathrm{a}]$ & $\begin{array}{c}\text { Temp. } \\
\left({ }^{\circ} \mathrm{C}\right)\end{array}$ & $\begin{array}{c}\operatorname{Time}^{[b]} \\
\text { (h) }\end{array}$ & $\begin{array}{c}\text { Conv. }{ }^{[c]} \\
(\%)\end{array}$ & $\begin{array}{c}M_{\mathrm{n}, \text { theo }}{ }^{[\mathrm{d}]} \\
\left(\mathrm{g} \cdot \mathrm{mol}^{-1}\right)\end{array}$ & $\begin{array}{l}M_{\mathrm{n}, \mathrm{NMR}^{[\mathrm{e}]}} \\
\left(\mathrm{g} \cdot \mathrm{mol}^{-1}\right)\end{array}$ & $\begin{array}{c}M_{\mathrm{n}, \mathrm{SEC}}^{[f]} \\
\left(\mathrm{g} \cdot \mathrm{mol}^{-1}\right)\end{array}$ & $\bigoplus_{\mathrm{M}}^{[\mathrm{f}]}$ & $P_{\mathrm{r}}^{[g]}$ \\
\hline 1 & OAll & $1 a$ & $53: 1: 1$ & 60 & 72 & 74 & 7550 & 7150 & 9200 & 1.46 & 0.07 \\
\hline 2 & OAll & $1 b$ & $54: 1: 1$ & 20 & 2 & 94 & 7800 & 7850 & 10500 & 1.09 & 0.10 \\
\hline 3 & OAll & 1c & $54: 1: 1$ & 20 & 2 & 39 & 3050 & 3300 & 4300 & 1.12 & 0.49 \\
\hline 4 & OAll & 1d & $50: 1: 1$ & 20 & 2 & 74 & 5300 & 5600 & 7200 & 1.11 & 0.51 \\
\hline 5 & OAll & $1 \mathrm{~g}$ & $51: 1: 1$ & 0 & 2 & 100 & 7250 & 7950 & 12150 & 1.39 & 0.91 \\
\hline 6 & OAll & $1 \mathrm{~g}$ & $55: 1: 1$ & 20 & 2 & 100 & 7850 & 7650 & 11000 & 1.19 & 0.88 \\
\hline 7 & OAll & $1 \mathrm{~g}$ & $108: 1: 1$ & 20 & 2 & 100 & 15290 & 15150 & 18300 & 1.14 & 0.84 \\
\hline 8 & OAll & $1 \mathrm{~h}$ & $53: 1: 1$ & 20 & 2 & 100 & 7500 & 7450 & 8600 & 1.23 & 0.82 \\
\hline 9 & OMe & 1b & $44: 1: 1$ & 20 & 2 & 84 & 4350 & 5200 & 5200 & 1.06 & 0.10 \\
\hline 10 & $\mathrm{OMe}$ & $1 \mathrm{~g}$ & $49: 1: 1$ & 20 & 2 & 100 & 5750 & 5750 & 8400 & 1.18 & 0.81 \\
\hline 11 & OMe & $1 \mathrm{~h}$ & $43: 1: 1$ & 20 & 2 & 100 & 5050 & 4950 & 6850 & 1.07 & 0.78 \\
\hline 12 & OBn & $1 b$ & $47: 1: 1$ & 20 & 2 & 98 & 9100 & 11550 & 11000 & 1.08 & 0.10 \\
\hline 13 & OBn & $1 \mathrm{~g}$ & $52: 1: 1$ & 20 & 2 & 100 & 10000 & 11400 & 16400 & 1.14 & 0.88 \\
\hline 14 & OBn & $1 \mathrm{~h}$ & $51: 1: 1$ & 20 & 2 & 100 & 9850 & 10050 & 10500 & 1.07 & 0.90 \\
\hline
\end{tabular}

a Reactions performed at $\left[\mathrm{BPL}{ }^{\mathrm{OR}}\right]_{0}=1.0 \mathrm{M}$. ${ }^{\mathrm{b}}$ Reaction time was not necessarily optimized. ${ }^{\mathrm{c}}$ Conversion of $\mathrm{BPL} \mathrm{OR}^{\mathrm{O}}$ as determined by ${ }^{1} \mathrm{H}$ NMR analysis of the crude reaction mixture. ${ }^{d}$ Molar mass calculated according to $M_{\mathrm{n}, \text { theo }}=\left(\left[\mathrm{BPL}{ }^{\mathrm{OR}}\right]_{0} /[1]_{0} \times\right.$ conv.BPLOR $\left.\times M_{\mathrm{BPLOR}}\right)+M_{\mathrm{PrOH}}$, with $M_{\mathrm{BPLOAll}}=142 \mathrm{~g} \cdot \mathrm{mol}{ }^{-1}$, $M_{\mathrm{iPrOH}}=60 \mathrm{~g} \cdot \mathrm{mol}^{-1}$. e Molar mass determined by ${ }^{1} \mathrm{H}$ NMR analysis of the isolated polymer, from resonances of the terminal OiPr group. ${ }^{\dagger} \mathrm{Number}-$ average molar mass and dispersity $\left(M_{\mathrm{w}} / M_{\mathrm{n}}\right)$ determined by SEC analysis in THF at $30{ }^{\circ} \mathrm{C} v \mathrm{v}$. polystyrene standards (uncorrected values). ${ }^{g} P_{\mathrm{r}}$ is the probability of racemic linkages between BPL ${ }^{\mathrm{OR}}$ units as determined by ${ }^{13} \mathrm{C}\left\{{ }^{1} \mathrm{H}\right\} \mathrm{NMR}$ analysis of the isolated $\mathrm{PHB}{ }^{\mathrm{OR}} \mathrm{S}$. 


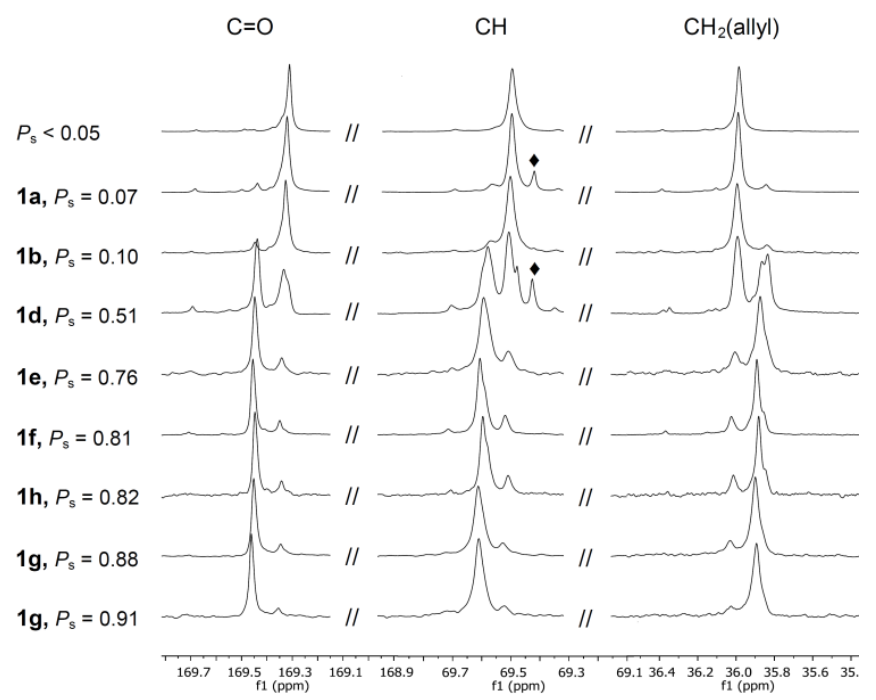

Figure 1. Detailed regions of ${ }^{13} \mathrm{C}\left\{{ }^{1} \mathrm{H}\right\}$ NMR spectra $\left(125 \mathrm{MHz}, \mathrm{CDCl}_{3}, 23{ }^{\circ} \mathrm{C}\right)$ of polymers prepared from the ROP of rac-BPL OAll (except top spectrum, from enantiopure $(S)$-BPLOAll) by $1 /$ PrOH $(1: 1)$ systems (Tables $1, \mathrm{~S} 1$ ). refers to residual monomer.

The tert-butyl substituted systems $\mathbf{1 e}$ and $\mathbf{1 f}$ induce a slightly less pronounced syndio-control than their cumyl-substituted analogues $\mathbf{1 g}$ and $\mathbf{1 h}$, respectively $\left(P_{\mathrm{S}}=0.76\right.$ vs. 0.88 and $0.81 \mathrm{vs}$. 0.82) (Tables $1, \mathrm{~S} 1){ }^{[17]}$ Performing the ROP of $r a c$-BPL ${ }^{\text {OAll }}$ at lower temperature $\left(0^{\circ} \mathrm{C}\right)$ with the $\mathbf{1 g} / \mathrm{iPrOH}$ system produced, as anticipated, a polymer with a higher $P_{\mathrm{s}}$ value of 0.91 (Table 1 , entry 5). Similar trends were observed for the ROP of rac-BPL ${ }^{\mathrm{OMe}}$ and rac-BPL ${ }^{\mathrm{OB}}$. The formation of highly syndiotactic $\mathrm{PHB}^{\mathrm{OR}}$ with " $\left\{\mathrm{ONOO}^{\mathrm{R}} 2\right\} \mathrm{Y}$ " catalysts bearing sterically crowded $\mathrm{R}^{\prime}(t \mathrm{Bu}$, $\mathrm{CMe}_{2} \mathrm{Ph}$ ) substituents follows trends previously established in the $\mathrm{ROP}$ of $r a c-\mathrm{BL},{ }^{[8,11]} \mathrm{rac}-\mathrm{MLA}^{\mathrm{R}}(\mathrm{R}=$ allyl, benzyl $),{ }^{[10]}$ and other $\beta$ lactones ${ }^{[9]}$ with related yttrium catalysts. This is consistent with a CEC mechanism where bulky substituents on the ligand platform favor discrimination between enantiomers of opposite configuration in a highly sterically crowded coordination sphere. Accordingly, systems 1c and 1d that are based on ligands with much less bulky methyl substituents afforded systematically atactic $\mathrm{PHB}^{\mathrm{OR}}$ materials $\left(P_{\mathrm{s}} \approx P_{\mathrm{i}}\right.$ ca. 0.50$)$, as clearly illustrated in the ${ }^{13} \mathrm{C}$ NMR spectra (Figure 1).

The most striking feature is the ability of dichloro-substituted systems $\mathbf{1 a}$ and $\mathbf{1 b}$ to give isotactic $\mathrm{PHB}^{\mathrm{OR}}$ materials. This is a completely original behavior since the same systems, when applied to the ROP of $r a c-\mathrm{LA},{ }^{[8 b]} r a c-\mathrm{BL}^{[10]}$ and $r a c-\mathrm{PMLA}^{\mathrm{R}}{ }_{\mathrm{S}},{ }^{[10]}$ formed atactic PLA and PHB and highly syndiotactic $\mathrm{PMLA}^{\mathrm{R}} \mathrm{S}$, respectively. Because $\mathrm{Cl}$ has a similar size to methyl, a steric origin of the isocontrol in the ROP of BPL ${ }^{\mathrm{OR}}$ can be ruled out. In this respect, the present phenomenon is quite different from that previously noted by Gibson et al. in the ROP of rac-LA with Al-salan type initiators, since in this latter case, the chloro-substituted systems actually afforded heterotactic PLA, just as the methyl-substituted systems did. $^{[2 e]}$ As expected from the achiral nature of our initiators, we checked that both enantiomers of $r a c-\mathrm{BPL}^{\mathrm{OAll}}$ are consumed at the same rate (Figures S20, S21), and hence that racemic mixtures of homochiral $(S)$ - and $(R)$ - $\mathrm{PHB}^{\mathrm{OAll}}$ are produced.

DFT studies have been performed to investigate the experimentally observed stereoselectivity of the catalysts. For the sake of computational resources, we have concentrated onto smallest catalysts 1a and 1c with BPL ${ }^{\mathrm{OAll}}$ as monomer. It should be noted that the mechanism of the elementary steps of ROP (ring-opening of the first monomer) is already well established, ${ }^{[18]}$ hence our focus was placed on the second step of the reaction determining the stereochemistry of the polymer (Figure 2) (see the Supporting Information for details). ${ }^{[19]}$

The free energies $(\Delta G)$ of the first two steps (attack of the monomer and formation of the four-membered metallacycle) for both iso- and syndioselective routes are similar. However, the second transition state leading to syndiotactic $\mathrm{PHB}^{\mathrm{OAll}}$ (III-SR-TS) is notably higher in energy $\left(\Delta G^{\ddagger}=11.6 \mathrm{kcal} \mathrm{mol}^{-1}\right)$ compared to the transition state leading to isotactic polymer (III-SS-TS, $\Delta G^{\ddagger}=6.2$ $\mathrm{kcal} \mathrm{mol}{ }^{-1}$ ). The origin of this difference was traced back to strong $\mathrm{C}-\mathrm{H} \cdots \mathrm{Cl}$ interactions between the ring-opened monomer and aromatic chloride substituents of the $\left\{\mathrm{ONXO}^{\mathrm{Cl}}\right\}^{2-}$ ligand (Figures 3 and S22, see the Supporting Information). Because the free energy of III-SS-TS is very low, the actual rate limiting step in the isoselective route is II-SS-TS with $\Delta G^{\ddagger}=7.1 \mathrm{kcal} \mathrm{mol}^{-1}$. Hence, the activation energy for the formation of isotactic $\mathrm{PHB}^{\mathrm{OAll}}$ is $4.5 \mathrm{kcal}$ $\mathrm{mol}^{-1}$ lower than for the syndiotactic polymer, which is in excellent agreement with the experimental result that $\mathbf{1 a}$ and $\mathbf{1 b}$ produce a highly isotactic material. It is very important to note that the strongest $\mathrm{C}-\mathrm{H} \cdots \mathrm{Cl}$ interaction exists between a hydrogen from the alkoxymethylene group $\left(-\mathrm{CHCH}_{2} \mathrm{OCH}_{2} \mathrm{CH}=\mathrm{CH}_{2}\right)$ that is replaced in alkoxycarbonyl- $\beta$-lactones $\left(\mathrm{MLA}^{\mathrm{R}}\right)$ by a carbonyl group ($\left.\mathrm{CHC}(=\mathrm{O}) \mathrm{OCH}_{2}-\mathrm{CH}=\mathrm{CH}_{2}\right)$. Not only this result elucidates the completely inverse behavior of $\left\{\mathrm{ONXO}^{\mathrm{Cl} 2}\right\}^{2-}$ ligand in the ROP of rac-MLA ${ }^{\mathrm{R}}$ and $r a c-\mathrm{PBL}^{\mathrm{OR}}$ monomers, but it also indicates that the mechanism of MLA ${ }^{\mathrm{R}}$ polymerization, producing highly syndiotactic PMLA $\left(P_{\mathrm{s}}>0.95\right),{ }^{[10 b]}$ is largely different than the above described route. Furthermore, because the strong interaction between this specific hydrogen and the aryl chloride substituent appears to be the main factor affecting the stereocontrol of the catalyst, it explains why different $\mathrm{R}$-groups in $\mathrm{PHB}^{\mathrm{OR}}$ ( $\mathrm{R}=$ allyl, Me, benzyl) do not have a significant impact onto the stereochemistry of the polymer (Tables 1, S1). ${ }^{[20]}$ The above calculations were repeated for methyl substituted catalyst 1c to estimate the differences between the substitution pattern of $\left\{\mathrm{ONXO}^{\mathrm{R}^{\prime} 2}\right\}^{2-}$ ligand. The ROP of $\mathrm{PHB}^{\mathrm{OAll}}$ using $1 \mathbf{c}$ as initiator proceeds through a similar route than that with

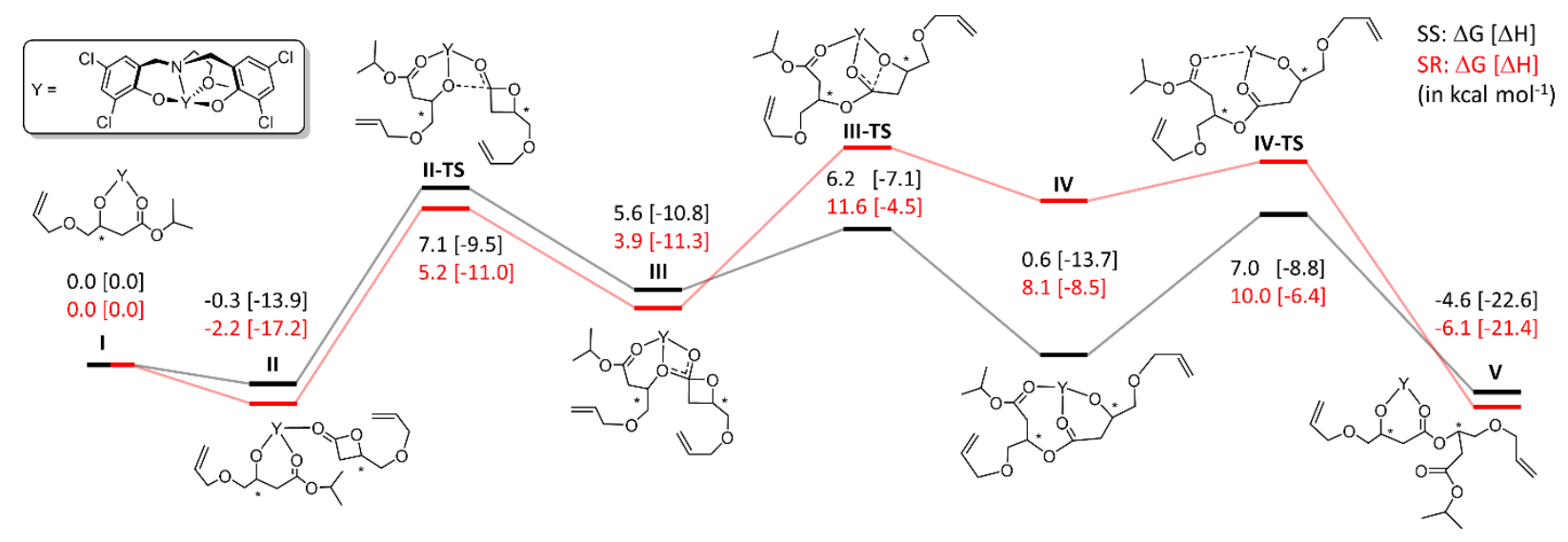

Figure 2. Energy profile of the proposed ROP mechanism for isotactic (black) and syndiotactic (red) PHB ${ }^{\text {OAll }}$ formation with 1a as initiator. 
1a. However, the energy profile of the reaction is significantly different (Figure S23). The free energies of almost all intermediates and transition states on both iso- and syndio-propagation routes are virtually identical. Interestingly, the difference in $\Delta G^{\ddagger}$ of the rate determining step (III-SS/SR-TS) is diminishingly small $(0.2 \mathrm{kcal}$ $\mathrm{mol}^{-1}$ ). This result is again in perfect agreement with the experimental observation that methyl substituted catalysts $\mathbf{1 c}$ and $\mathbf{1 d}$ produce practically atactic $\mathrm{PHB}^{\mathrm{OR}}$.

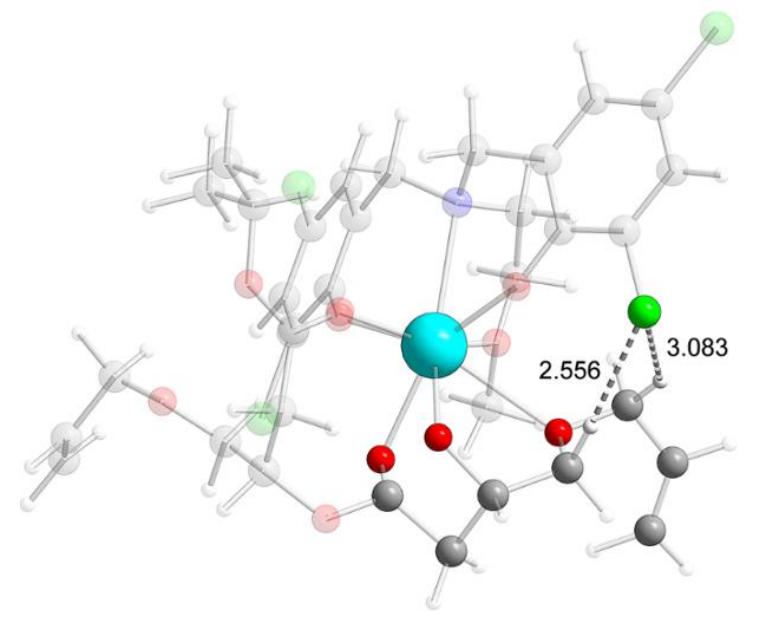

Figure 3. Structure of III-SS-TS showing the shortest $\mathrm{CH} \cdots \mathrm{Cl}$ distances (blue = $\mathrm{Y}$, red $=\mathrm{O}$, green $=\mathrm{Cl}$, dark grey $=\mathrm{C}$, light grey $=\mathrm{H}$ ) (see also the Supp. Info.).

The thermal properties of the $\mathrm{PHB}^{\mathrm{OR}} \mathrm{S}$ were preliminarily investigated by DSC (Table S3, Figures S24-S29). These analyses revealed that a distinct glass transition temperature between purely isotactic $\left(P_{\mathrm{i}}>0.95\right)$ and syndiotactic $\left(P_{\mathrm{s}}>0.90\right)$ polyesters could only be observed for $\mathrm{PHB}^{\mathrm{OMe}}\left(T_{\mathrm{g}} i s o=-18^{\circ} \mathrm{C}\right.$ vs $T_{\mathrm{g}}$ syndio $=\mathrm{ca}$. $\left.+12{ }^{\circ} \mathrm{C}\right)$. For isotactic $\mathrm{PHB}^{\mathrm{OR}} \mathrm{s}$, the alkoxymethylene substituent on the repeating unit was found to significantly affect this value $\left(T_{\mathrm{gPHBO}}\right.$ All $\left.=-39^{\circ} \mathrm{C}, T_{\mathrm{gPHBOMe}}=-18^{\circ} \mathrm{C}, T_{\mathrm{gPHBOBn}} 0^{\circ} \mathrm{C}\right)$. Finally, a melting transition temperature was only observed for syndiotactic $\mathrm{PHB}^{\mathrm{OR}} \mathrm{S}$ with $\mathrm{R}=\mathrm{All}$, Me $\left(T_{\mathrm{mPHBOAll}}=+85^{\circ} \mathrm{C}-\mathrm{a}\right.$ similar value to that reported for PMLA $\left.{ }^{\mathrm{All}},[10]-T_{\mathrm{mPHBOMe}}=+116^{\circ} \mathrm{C}\right)$.

In conclusion, we have demonstrated for the first time that a specific class of functional racemic $\beta$-lactones can be polymerized either in a syndioselective, or most originally, in an isoselective fashion by simple tuning of a given catalyst. Chloro substituents on the tetradentate bisphenolate ligand have a unique influence. DFT computations hint at the determining role of $\mathrm{Cl} \cdots \mathrm{H}$ interactions between the ligand and growing polymer chain in enabling the isoselective ROP of $\mathrm{BPL}^{\mathrm{OR}}$ monomers. Most interestingly, the stereocontrol ability of these $o, p$-dichloro-substituted yttrium catalysts appear to be very different between $r a c-\mathrm{BPL}^{\mathrm{OR}}$ and $\mathrm{rac}$ $\mathrm{MLA}^{\mathrm{R}}$ monomers, leading respectively to iso- and syndiotactic PHAs. These unique stereocontrol abilities are prone to be applied to the preparation of original polymer materials derived from various cyclic esters.

Received: ((will be filled in by the editorial staff))

Published online on ((will be filled in by the editorial staff))

Keywords: $\beta$-lactones • stereoselective catalysis • ring-opening polymerization $\cdot$ yttrium
[1] For recent leading reviews, see: a) Handbook of Ring-Opening Polymerization; P. Dubois, O. Coulembier, J.-M. Raquez Eds.; Weinheim: Wiley, 2009; b) C. M. Thomas, Chem. Soc. Rev., 2010, 39, $165-173$; c) A. Buchard, C. M. Bakewell, J. Weiner, C. K. Williams, Top. Organomet. Chem., 2012, 39, 175-224; d) W. N. Ottou, H. Sardon, Haritz; D. Mecerreyes, J. Vignolle, Joan; D. Taton, Prog. Polym. Sci, 2016, 56, 64-115.

[2] For selected leading references, see: c) T. M. Ovitt, G. W. Coates, $J$. Am. Chem. Soc., 2002, 124, 1316-1326; b) Z. Zhong, P. J. Dijkstra, J. Feijen, Angew. Chem. Int. Ed., 2002, 41, 4510-4513; c) N. Nomura, R. Ishii, M. Akakura, K. Aoi, J. Am. Chem. Soc., 2002, 124, 5938-5939; d) N. Nomura, R. Ishii, Y. Yamamoto, T. Kondo, Chem. Eur. J., 2007, 13, 4433-4451; e) P. Hormnirum, E. L. Marshall, V. C. Gibson, A. J. P. White, D. J. Williams, J. Am. Chem. Soc., 2004, 126, 2688-2689; f) P. Hormnirun, E. L. Marshall, V. C. Gibson, R. I. Pugh, A. J. P. White Proc. Nat. Acad. Sci., 2006, 103, 15343-15348; g) P. J. Dijkstra, H. Du, J. Feijen, Polym. Chem., 2011, 2, 520-527; h) A. Pilone, K. Press, I. Goldberg, M. Kol, M. Mazzeo, M. Lamberti, J. Am. Chem. Soc., 2014, 136, 2940-2943; i) P. McKeown, M. G. Davidson, G. KociokKöhn, M. D. Jones, Chem. Commun., 2016, 52, 10431-10434.

[3] a) A. F. Douglas, B. O. Patrick, P. Mehrkhodavandi, Angew. Chem. Int. Ed., 2008, 120, 2322-2325; b) D. C. Aluthge, B. O. Patrick, P. Mehrkhodavandi, Chem. Commun., 2013, 49, 4295-4297; c) D. C. Aluthge, J. M. Ahn, P. Mehrkhodavandi, Chem. Sci., 2015, 6, 5284-5292; d) D. Myers, A. J. P. White, C. M. Forsyth, M. Bown, C. K. Williams, Angew. Chem. Int. Ed., 2017, DOI: 10.1002/anie.201701745.

[4] a) H. Wang, H. Ma, Chem. Commun. 2013, 49, 8686; b) S. Abbina, G. Du, ACS Macro Lett., 2014, 3, 689-692; c) Z. Mou, B. Liu, M. Wang H. Xie, P. Li, L. Li, S. Lia, D. Cui, Chem. Commun., 2014, 50, 1141111414 ; d) T. Rosen, Y. Popowski, I. Goldberg, M. Kol, Chem. Eur. J., 2016, 22, 11533-11536.

[5] a) M. D. Jones, S. L. Hancock, P. McKeown, P. M. Schäfer, A. Buchard, L. H. Thomas, M. F. Mahon, J. P. Lowe, Chem. Commun. 2014, 50, 15967-15970; b) M. D. Jones, L. Brady, P. McKeown, A Buchard, P. M. Schäfer, L. H. Thomas, M. F. Mahon, T. J. Woodman, J. P. Lowe, Chem. Sci., 2015, 6, 5034-5039.

[6] a) P. L. Arnold, J.-C. Buffet, R. P. Blaudeck, S. Sujecki, A. J. Blake, C. Wilson, Angew. Chem. Int. Ed., 2008, 47, 6033-6036; b) C. Bakewell, T. P. Cao, N. Long, X. F. Le Goff, A. Auffrant, C. K. Williams, J. Am. Chem. Soc., 2012, 134, 20577-20580; c) C. Bakewell, A. J. P. White, N. J. Long, C. K. Williams, Angew. Chem. Int. Ed., 2014, 53, 9226-9230; d) T.-Q. Xu, G.-W. Yang, C. Liu, X.-B. Lu, Macromolecules, 2017, 50, 515-522.

[7] J.-F. Carpentier, Macromol. Rapid Commun. 2010, 31, 1696-1705

[8] a) A. Amgoune, C. M. Thomas, S. Ilinca, T. Roisnel, J.-F. Carpentier, Angew. Chem. Int. Ed. 2006, 45, 2782-2784; b) M. Bouyahyi, N. Ajellal, E. Kirillov, C. M. Thomas, J.-F. Carpentier, Chem. Eur. J., 2011, 17, 1872-1883; c) J.-F. Carpentier, Organometallics, 2015, 34 , 4175-4189; d) N. Ajellal, M. Bouyahyi, A. Amgoune, C. M. Thomas, A. Bondon, I. Pillin, Y. Grohens, J.-F. Carpentier, Macromolecules, 2009, 42, 987-993.

[9] J. W. Kramer, D. S. Treitler, E. W. Dunn, P. M. Castro, T. Roisnel, C. M. Thomas, G. W. Coates, J. Am. Chem. Soc., 2009, 131, 16042 16044.

[10] a) C. G. Jaffredo, Y. Chapurina, S. M. Guillaume, J.-F. Carpentier, Angew. Chem. Int. Ed., 2014, 53, 2687-2691; b) C. G. Jaffredo, Y. Chapurina, E. Kirillov, J.-F. Carpentier, S. M. Guillaume, Chem. Eur. J., 2016, 22, 7629-7641.

[11] P. T. Altenbuchner, A. Kronast, S. Kissling, S. I. Vagin, E. Herdtweck, A. Pöthig, P. Deglmann, R. Loos, B. Rieger, Chem. Eur. J., 2015, 21, 13609-13617.

[12] a) M. Zintl, F. Molnar, T. Urban, V. Bernhart, P. Preishuber-Pflügl, B. Rieger, Angew. Chem. Int. Ed., 2008, 47, 3458-3460; b) R. Reichardt, S. Vagin, R. Reithmeier, A. K. Ott, B. Rieger, Macromolecules 2010 , 43, 9311-9317; c) S. Vagin, M. Winnacker, A. Kronast, P. T. Altenbuchner, P. Deglmann, C. Sinkel, R. Loos, B. Rieger, ChemCatChem, 2015, 7, 3963-3971.

[13] a) J. Kramer, E. B. Lobkovsky, G. W. Coates, Org. Lett., 2006, 8, 3709-3712; b) J. A. R. Schmidt, E. B. Lobkovsky, G. W. Coates, J. Am. Chem. Soc. 2005, 127, 11426-11435.

[14] For the ROP of BPL ${ }^{\text {OAll }}$ (similar operating conditions), using $\mathbf{1 b}$ Conv. BPLOAll $=$ traces in THF vs. $94 \%$ in toluene $($ Table 1 , entry 2$)$; 
using 1d: Conv. BPLOAll $=49 \%$ in THF $\left(P_{\mathrm{r}}=0.53\right)$ vs. $74 \%$ in toluene $\left(P_{\mathrm{r}}=0.51\right)$ (Table 1, entry 4); using 1g: Conv. $\cdot$ BPLOAll $=59 \%$ in $\mathrm{THF}\left(P_{\mathrm{r}}\right.$ $=0.83)$ vs. $100 \%$ in toluene $\left(P_{\mathrm{r}}=0.88\right)$ (Table 1 , entry 6).

[15] C. G. Jaffredo, M. Schmid, I. del Rosal, T. Mevel, P. W. Roesky, L. Maron, S. M. Guillaume, Chem. Eur. J. 2014, 20, 14387-14402.

[16] Systems based on a methoxy-capped ligand proved generally to be more stereoselective than their $\mathrm{NMe}_{2}$-capped analogues; compare e.g. $1 \mathrm{a}$ vs $\mathbf{1 b}$ and $1 \mathrm{~g}$ vs $1 \mathrm{~h}$.

[17] The presence of additional signals/shoulders indicates that there is also information at a larger range (triads) but this could not be further developed due to the poor resolution of these signals.

[18] J. Fang, M. J. L. Tschan, T. Roisnel, X. Trivelli, R. M. Gauvin, C. M Thomas, L. Maron, Polym. Chem. 2013, 4, 360-367.

[19] The large number of carbonyl and ether oxygens able to coordinate to yttrium center (particularly after the first ring-opening cycle) should favor the mononuclear complexes during the polymerization process. The possibility of dinuclear initiation, evoked earlier in the ROP of rac-MLA ${ }^{\mathrm{R}}$ [10b], is most unlikely in the present case, as experiments performed on a 3-fold range of catalyst concentration indicated the apparent rate constants to be first order dependent on the yttrium concentration (see Table S2 and Figure S2 in the Supporting Information); also, the tacticity was not affected within this range of concentration $\left(P_{\mathrm{m}}=0.10\right)$.

[20] The activity of $\mathbf{1 a} / \mathbf{1} \mathbf{b}$ in ROP of $r a c-\mathrm{BPL}^{\mathrm{OR}}$ at room temperature in THF is almost nil and we therefore could not assess whether the stereoselectivity is affected or not when reactions are performed in such a coordinating solvent (see [14]). 
Polymer Chemistry

Romain Ligny, Mikko M. Hänninen, Sophie M. Guillaume, ${ }^{*}$ Jean-François Carpentier*

Page - Page

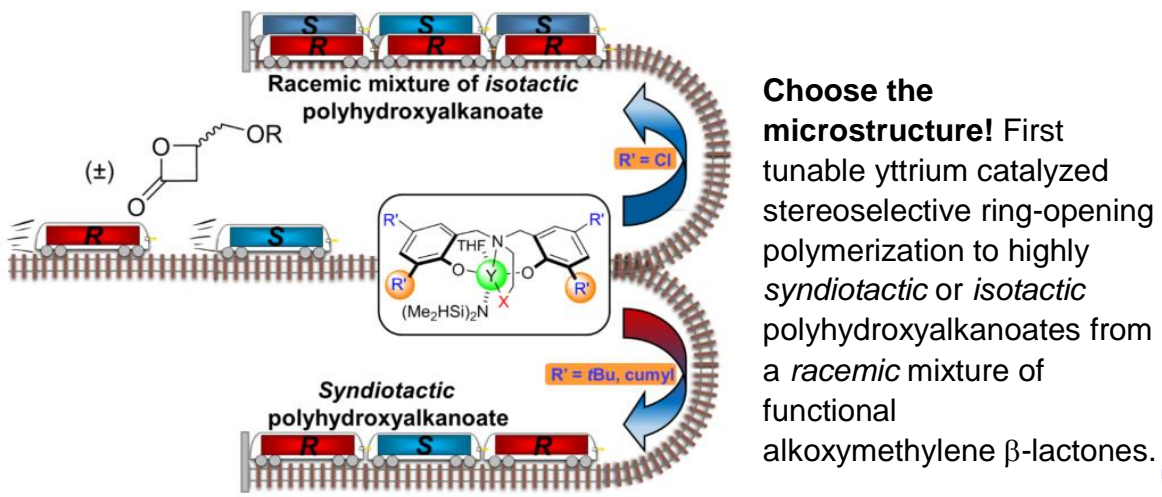

